\title{
Work Orientation in Korean CEO's On-line Greetings
}

\section{Associate Professor, Yeonkwon Jung, Kansai Gaidai University, Japan}

\begin{abstract}
The main aim of the study is to explicate prior orientation to work and priorities in what Korean companies wants from their work. CEO's on-line greeting texts in big three Korean companies (Hyundai Motors; LG Corp.; Samsung Electronics) are chosen as major data of the study. Eccles and Nohria's (1992) Strategic Triadic is used as a framework for data analysis. This study exemplifies that communication orientation to stakeholders is different across companies (i.e. Hyundai's globalization; LG's customer value; Samsung's excellence). Furthermore, this finding shows that actual code of conduct emphasized by the CEOs is not going well with official corporate values.
\end{abstract}

Keywords: work orientation, Korean, CEO, on-line greeting, rhetoric 


\section{Introduction}

This study deals with nature of public relations communication articulated in the different codes of conduct published by three Korean companies. It exemplifies that each company differentiates on-line public relations communication. It suggests linguistic code of conducts that Chief Executive Officers (CEOs) highlight when formulating on-line messages for stakeholders. It explicates whether each code of conduct is clarified in the greeting genre. In other words, this study investigates whether the code is properly incorporated into the CEO's on-line public relations communication and whether companies put stress on different codes of conduct. Public relations communication is communication for an organization's reputation management. It is communication serving an inter-mediated function that helps business organizations boost/maintain/restore their corporate face by facilitating internal and external communications with stakeholders using proper media (Jung 2007). This study aims to help stakeholders make sense of organizational behaviors and words, which can be manipulated and shaped from corporate codes of conduct, guidelines for appropriate behavior in certain organizations. Organizational codes play a crucial role in shaping corporate laws and regulations and they can be controlled by top management of an organization. This study investigates social interactions in an on-line writing genre, looking at types and frequencies of languages top executives use in the ways they do in contemporary business world. It identifies language components CEOs may use to communicate with stakeholders on-line. In this study, language components solely accommodate "rhetoric as (nominalized) action" in order to link between textual features and corporate code of conduct (Eccles and Nohria 1992). It is because my intent is not to determine "rhetoric as identity" realized by sentence subjects (e.g. company name, business 'we'). Accordingly, this study only explores textual features related to action for fulfilling organizational goals are involving noun (phrases) (e.g. 
Sangsayng 'co-prosperity') and/or nominalized verbs (e.g. Kokaykuy chapyelhwatoyn kachi ceykong 'Creating value for customer').

This study explicates contemporary Korean companies' codes of conduct incorporated into corporate value, corporate philosophy, business and/or management principle, and corporate vision through 2010 Korean CEO's on-line greetings in big three Korean companies (Hyundai Motors; LG; Samsung Electronics (alphabetical order)). CEO's on-line greeting texts are chosen as major data of the study. It is because CEO's on-line greeting might be the most fundamental genre to facilitate an interaction with key stakeholders among many other public relations communication genres. It is posted on the company website for all to see, so that all the stakeholders can be easily accessible to it. Nevertheless, presumably it is likely to be seen by CEOs as less important internally than externally, as major readership may be outside company.

Among the 2010 Fortune global 500 companies, top three Korean companies (which may also be generally perceived as top three Korean companies among local Koreans) are chosen for the study, as shown in the following figure. 


\begin{tabular}{llllr}
$\begin{array}{l}\text { Country } \\
\text { Rank }\end{array}$ & Company & $\begin{array}{l}\text { Global } \\
500 \\
\text { rank }\end{array}$ & City & $\begin{array}{r}\text { Revenues } \\
\text { (S millions) }\end{array}$ \\
\hline 1 & Samsung Electronics & 32 & Seoul & 108,927 \\
\hline 2 & LG & 67 & Seoul & 78,892 \\
\hline 3 & Hyundai Motor & 78 & Seoul & 71,678 \\
\hline 4 & SK Holdings & 104 & Seoul & 64,396 \\
\hline 5 & POSCO & 272 & Seoul & 28,883 \\
\hline 6 & GS Holdings & 300 & Seoul & 27,066 \\
\hline 7 & Korea Electric Power & 306 & Seoul & 26,640 \\
\hline 8 & Samsung Life Insurance & 316 & Seoul & 25,805 \\
\hline 9 & Hanwha & 358 & Seoul & 23,521 \\
\hline 10 & Hyundai Heavy Industries & 375 & Ulsan & 22,926
\end{tabular}

Figure 1. Top 10 Korean companies in the 2010 Fortune global 500 companies

This study explores whether a particular industry affects the choice of type and frequency of textual code of conduct. Special attention is paid on which language codes are actually highlighted in 'the representative corporate voice genre'. It tries to address the following research questions: How does PR communication realize in CEO's on-line greetings?; Which code of conduct is highlighted?; What language features might CEOs consider to initiate and guide corporate activities?; What are key textual components in the language of management?; Is the code of conduct highlighted in the CEO's greetings going well with official corporate code of conduct?

The complexity of management's concerns and its language choice to articulate the concerns are expected to tell us each company's exclusive keyword-based management language.

This paper is organized in the following way. The first half of the paper investigates big three Korean companies' vision and management principle. The second half of the paper explores 
language components in Korean CEO's on-line greetings. This study claims that communication orientation to work depends on the specific organizational context, and concludes with implications for pedagogy and future research. Before detailed analysis, I would like to provide a brief description of literature review on the management language.

\section{Literature review on the management language}

A review of business communication and English for Specific Purposes reveal few studies of text-linguistic feature analyses for management. Much has been written about the code of conduct for shaping workplace realities and articulating business strategic shifts (cf. Bird 2007; Fairhurst 2005). For example, studies examine framing (Fairhurst et al., 1997; Goffman 1974; Lakoff 2004), using metaphor for administrative activities (Morgan 1983), building a corporate culture (David \& Graham 1997), altering business performance (Suchan 1992), and managing diversity in organizations (Kirby \& Harter 2003). These studies have a tendency to focus on the social constructs rather than the language use.

Despite their crucial function in formulating the corporate code of conduct, less is known about CEOs' use of textual components as the language of management. Among few studies on the use of management language, Ran and Duimering (2007) investigate how language is used for organizational identity claims in corporate mission statements. Rogers and Swales (1990) explicate Dana Corporation's 1987 The Philosophy and Policies of Dana intriguing for its use of sentence subjects that create an inclusive tone while communicating management goals. Like these few studies, this study also sheds light on the use of language features as tools for management. Before moving on to the analysis of CEO's on-line PR texts, let us look into each Korean company's vision, management policy, business and management principle, and corporate values. 


\section{Big Three Korean Companies' Corporate Values}

This section introduces corporate code of conduct through company's vision, management policy, business and management principle, and corporate values described in target companies' website.

\subsection{Hyundai Motors}

Hyundai Motor Company is a Korean multinational automaker headquartered in Seoul, Korea. Hyundai was founded in 1967 and it, along with Kia, together comprise the Hyundai Kia Automotive Group, which is the world's fourth largest automobile manufacturer, as of 2009. As of 2011, it is the world's fastest growing automaker for two years running. In 2008, Hyundai (without Kia) ranked as the eighth largest automaker. In 2010, Hyundai sold over 3.6 million vehicles worldwide. Hyundai operates the world's largest integrated automobile manufacturing facility in Ulsan, which is capable of producing 1.6 million units annually. The company employs about 75,000 people worldwide. Hyundai vehicles are sold in 193 countries through some 6,000 dealerships and showrooms (cited from Wikipedia (http://en.wikipedia.org/wiki/Hyundai_Motor_Company)).

Hyundai Motors announce kokaykul uyhan hyeksin "Innovation for Customers" as their midto long-term vision with five core strategies: global orientation, respect for human values, customer satisfaction, technology innovation, and cultural creation. Their vision, innovation for customers, orients to customers in terms of technology innovation. Customer values are highlighted, as clarified in two of their five core business strategies to achieve corporate values, respect for human values and customer satisfaction. 
Unlike people-oriented corporate vision, however, Hyundai Motors Management Policy shows that they pay particular attention to the value of integrity (i.e. a type of ethical code; transparency in Hyundai Motors' corporate image), as figure 1 supports the claim. Two management policies, trust-based management and transparent management, are rooted in the value of integrity. On-site management is regarding global orientation to expand their market share through managing local people relations.

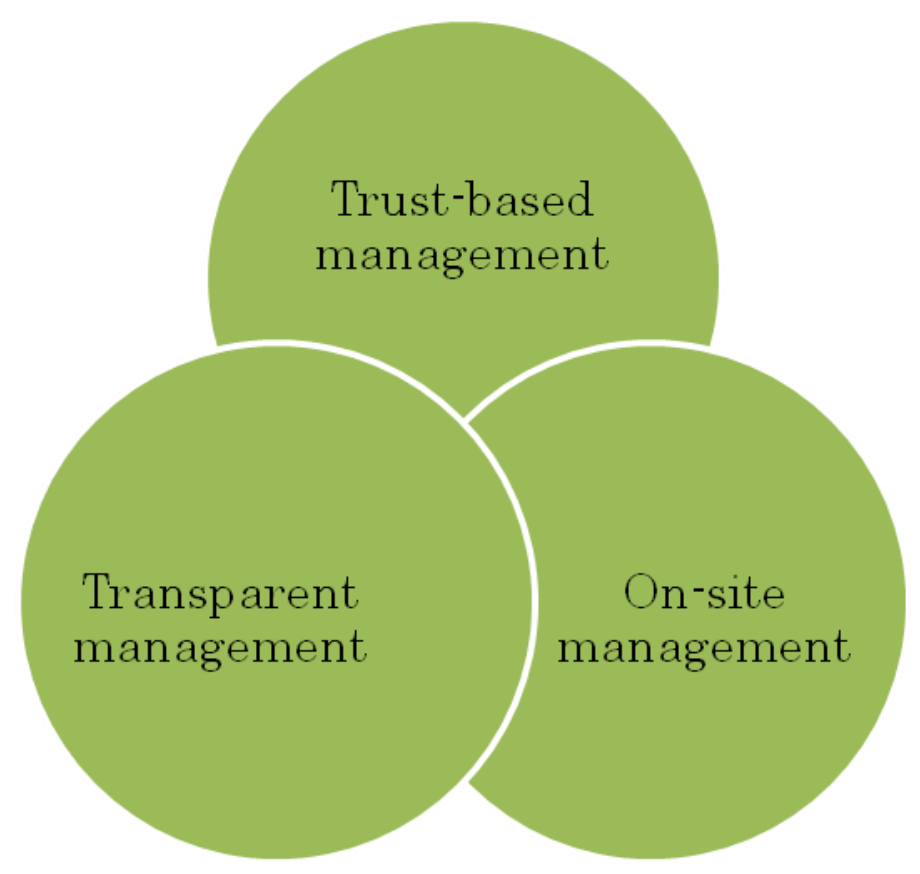

Figure 1. Hyundai Motors Management Policy (adapted from Hyundai Motors website (http://www.hyundai.com/kr/))

\subsection{LG}

LG Corp. is the second-largest Korean conglomerate company following Samsung, and it is headquartered in the LG Twin Towers in Seoul. LG produces electronics, chemicals, and telecommunications products and operates subsidiaries like LG Electronics, LG Display, LG Telecom and LG Chem in over 80 countries. (cited from Wikipedia 
(http://en.wikipedia.org/wiki/Lg_group)).

LG vision is described through the so-called LG Way, LG's core beliefs, values, and aspirations. The LG Way is a vision that guides the thoughts and actions of LG employees in attaining the ultimate goal of their business. The LG Way is reached through the practice of Jeong-Do Management and LG's management principles, "Creating value for customers" and "Respecting human dignity“. The English translation of Jeong-Do is "the right way." JeongDo Management is the way LG display their uncompromising integrity in pursuing LG's management principles. It clarifies that LG's core management styles are incorporated into their corporate values. First, the LG's business principle of Jeong-Do management is relevant to a type of business ethical code, integrity, as in the case of Hyundai Motors' management policy. Second, human orientation described as "Creating value for customers" and "Respecting human dignity“ is another key value in LG.

\subsection{Samsung Electronics}

Samsung Electronics is a Korean multinational electronics and information technology company headquartered in Samsung Town, Seoul. It is the flagship subsidiary of the Samsung Group. With assembly plants and sales networks in 61 countries across the world, Samsung has approximately 160,000 employees. In 2009, the company took the position of the world's biggest IT maker by surpassing the previous leader Hewlett-Packard. Its sales revenue in the areas of LCD and LED displays and memory chips is number one in the world. In the TV segment, Samsung's market position is dominant. For the five years since 2006, the company has been in the top spot in terms of the number of TVs sold, which is expected to continue in 2010 and beyond. In the global LCD panel market, the company has kept the leading position for eight years in a row. With the Galaxy $\mathrm{S}$ model mobile phone, Samsung's smartphone 
lineup has retained the second-best slot in the world market for some time. (cited from Wikipedia (http://en.wikipedia.org/wiki/Samsung_Electronics))

Samsung Electronics suggest five "atomic" corporate values, People, Excellence, Change, Integrity, and Co-prosperity. As shown in figure 2, likewise, they introduce five business principles. Among those, we can see that they intensify the value of integrity as in the previous two Korean companies. That is, two of their business principles below, "We comply with laws and ethical standards" and "We maintain a clean organizational culture", are related to a type of business ethical code, integrity. Unlike Hyundai Motors and LG, however, Samsung Electronics put stress on the value of co-prosperity with local community in terms of taking corporate social responsibility, as introduced in their business principles, "We care for the environment, health and safety" and "We are a socially responsible corporate citizen".

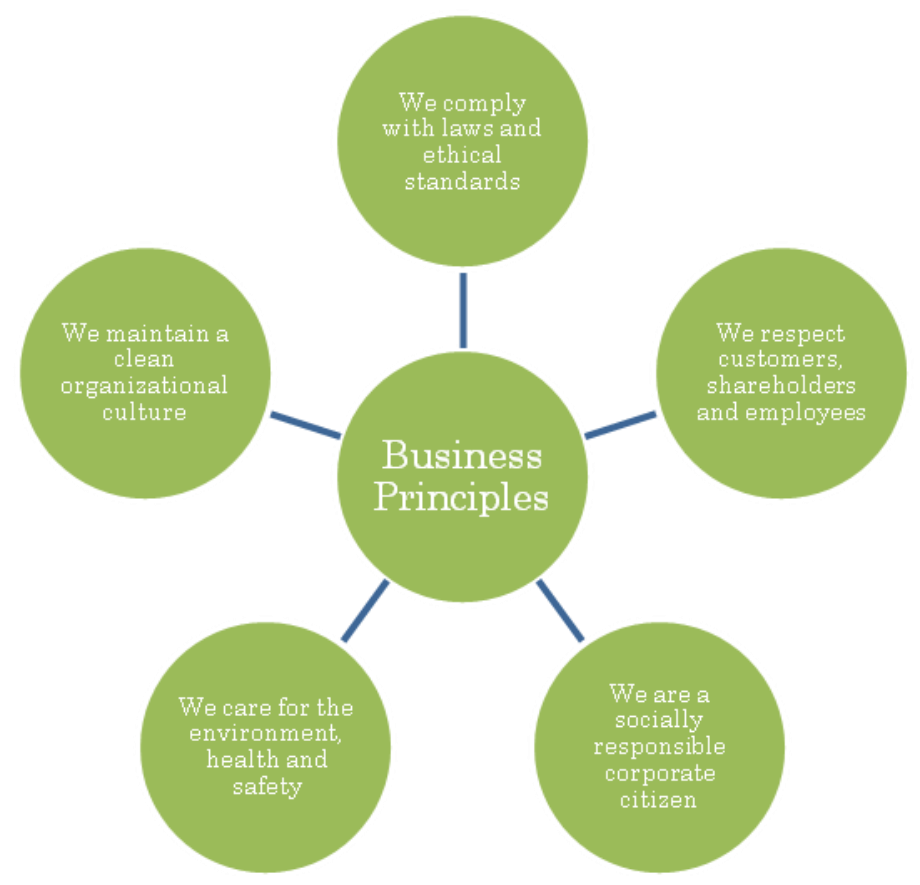

Figure 2. Samsung Electronics Business Principle (adapted from Samsung Electronics' website (http://www.samsung.com/sec/)) 
So far we look at each Korean company's corporate value, corporate philosophy, business and/or management principle, and corporate vision. They can be summarized as follows:

\begin{tabular}{|c|c|c|}
\hline & Vision/value & Management policy/principle \\
\hline Hyundai Motors & Innovation for Customers & $\begin{array}{l}\text { - Trust-based management } \\
\text { - Transparent management } \\
\text { - On-site management }\end{array}$ \\
\hline LG & LG Way & $\begin{array}{l}\text { - Jeong-Do Management } \\
\text { - Creating value for customers } \\
\text { - Respecting human dignity }\end{array}$ \\
\hline Samsung Electronics & $\begin{array}{l}\text { People, Excellence, Change, } \\
\text { Integrity, Co-prosperity }\end{array}$ & $\begin{array}{l}\text { - Compliance with laws and } \\
\text { ethical standards } \\
\text { - Maintenance of a clean } \\
\text { organizational culture } \\
\text { - Care for the environment, health } \\
\text { and safety } \\
\text { - Socially responsible corporate } \\
\text { citizen } \\
\text { Respect for customers, } \\
\text { shareholders and employees }\end{array}$ \\
\hline
\end{tabular}

Table 1. The Korean companies' vision and management principle

Each company's vision and management principle in table 1 look different each other. However, they actually share same values as summarized in table 2. As shown in table 2, integrity and people are common values in all the Korean companies. 


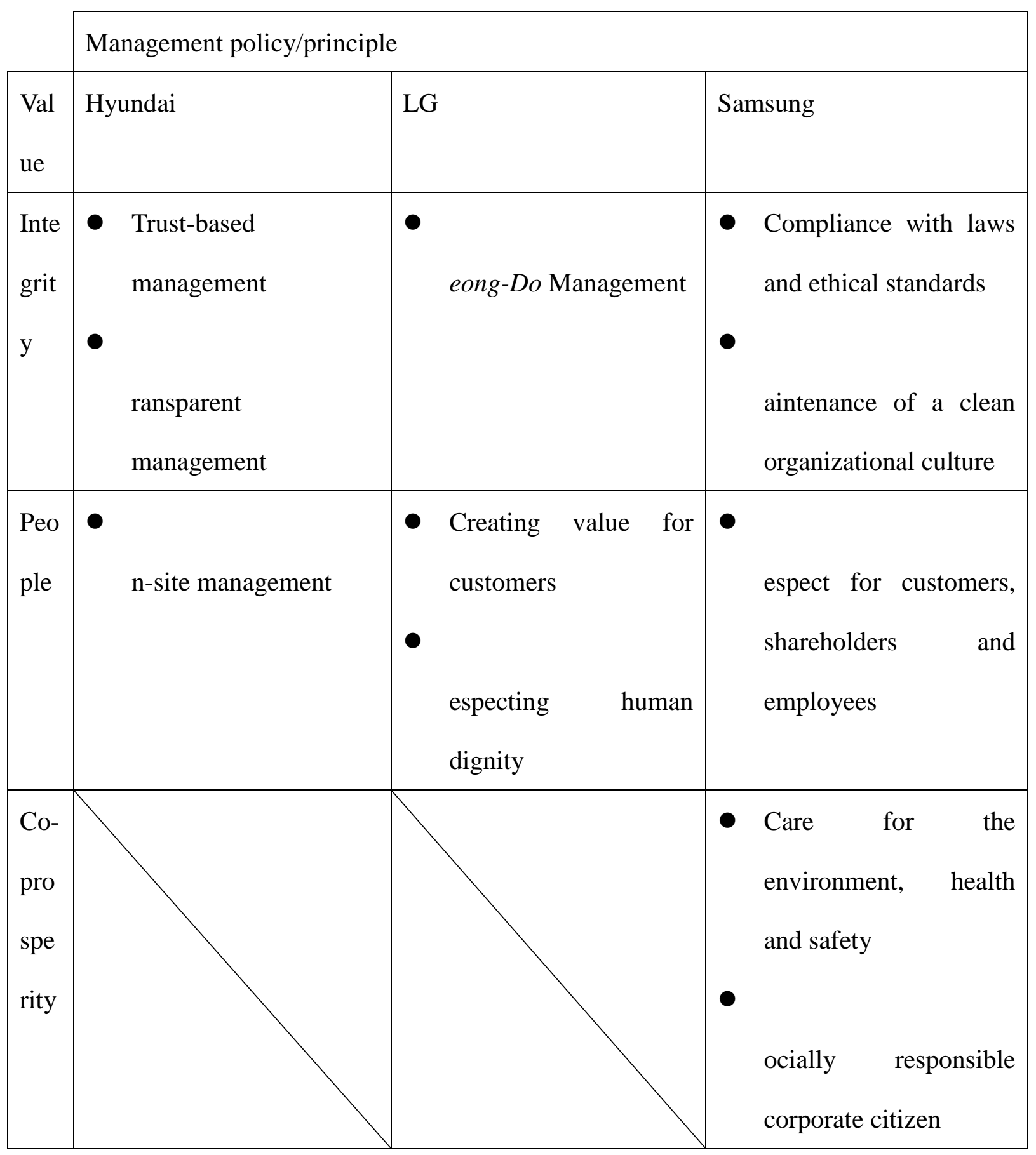

Table 2. Corporate value and management style in each company

Now let us explicate how these values and management styles are incorporated into the Korean CEO's greetings publicized in each company's website. 


\section{Language components in Korean CEO's On-line Greetings}

Eccles and Nohria's (1992) Strategic Triadic is used as a framework for data analysis. The Strategic Triadic is composed of three interdependent elements, action, identity, and rhetoric, and the three elements are the basis for effective management.

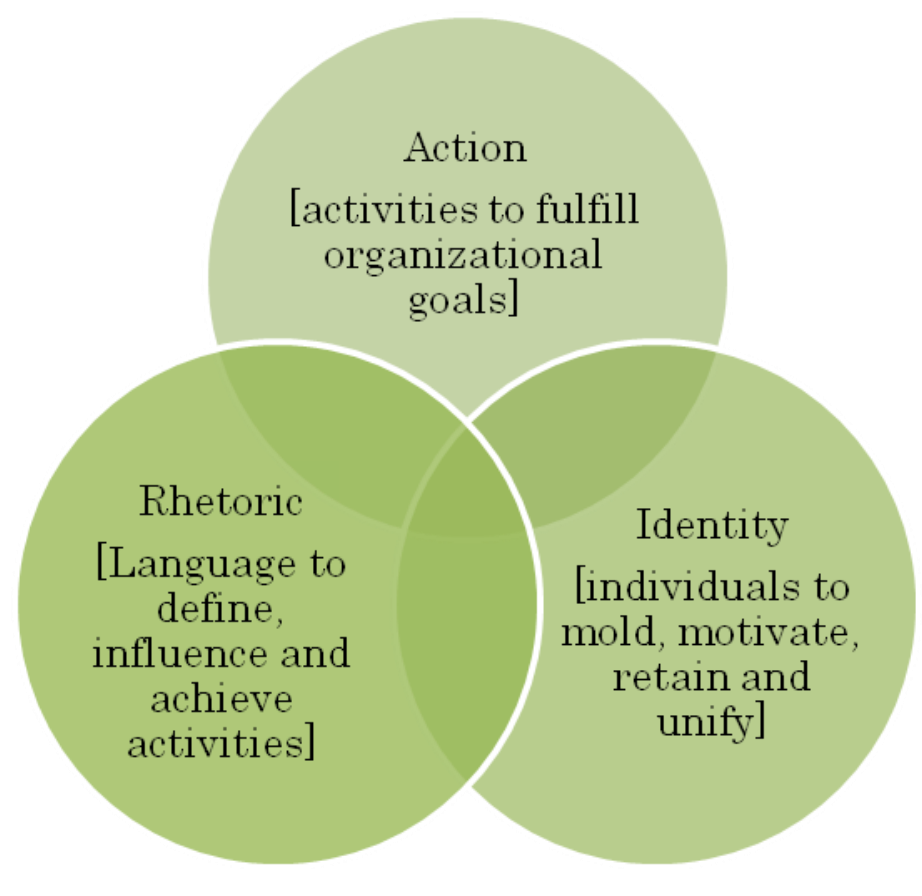

Figure 3. Eccles and Nohria's (1992) Strategic Triadic

Action is regarding activities to fulfill organizational goals or revising performance expectations. Intertwined with action is "how identities get built and maintained in organizations, and how the quest for personal identity... is an inseparable aspect of everything that occurs" (Eccles and Nohria 1992:12). Integral to action and identity is rhetoric or "the way human beings interact to get things done" and "how language is used to shape the way people think and act" (Eccles and Nohria 1992: 9-10).

In this study, language components as units for data analysis solely accommodate "rhetoric as action", not "rhetoric as identity" (see Rogers and Swales (1990) for "rhetoric as identity"). 
That is, this study explores textual features related to action for fulfilling organizational goals are involving noun (phrases) (e.g. Cisokcekin sengkwa 'sustainable achievement') and/or nominalized verbs (e.g. Kokaykuy chapyelhwatoyn kachi ceykong 'Creating value for customer'), not related to identity realized by sentence subjects (e.g. company name, business 'we'). Accordingly, language components in the study are not seen as an agent to conduct business work in daily operations, but rather an instrument to get business work done or to provide direction for the way things get done.

\subsection{Hyundai Motors}

CEO in Hyundai Motors introduces four codes of conduct in his on-line greeting, global orientation, customer, co-prosperity, and sustainability. Among those codes, the value of global orientation is highest in frequency in compare with three others (e.g. Kullopel kyengyengcheycey kwuchwuk 'Establishing a global management system'; Kullopel catongcha meyikhe 'Global car maker'; Kullopel ritelo toyak 'Taking the leap to becoming a global leader'; Kullopel sayngsankecemuy kyengyeng ancenghwa 'Management stabilization of global manufacturing footprints'; Kullopel choillyu kiepulo sengcang 'Developing into a global no. 1 corporation'; Kullopel sahoykonghen hwaltong 'Taking global corporate social responsibility'. This finding does not seem to go along well with the claim that their vision orients to customers through technology innovation as a primary corporate vision and integrity realized by "trust-based management" and "transparent management" as a fundamental management policy (see section 3.1. for their vision and management policy). Besides global orientation, kokayk 'customer', sangsayngkyengyeng 'co-prosperity', and cisokkanung 'sustainability' are also mentioned as key corporate codes, as given in the following textual examples: Cungcangki picenin kokaykul uyhan hyeksin 'Innovation for customers as mid-to long-term vision'; Kokaykul choywusenulo hanun kyengyengchelhak 
'business philosophy placing customers as highest priority'; Sangsayngkyengyengul kanghwa 'Strengthening co-prosperity management'; Kullopel sahoykonghen hwaltong 'Taking global corporate social responsibility'; Hwankyengul uyhan kiswulul kaypal pokup 'Eco-friendly technological innovation'; Cisokkanung 'Sustainability'

\subsection{LG}

LG's CEO values people, including human resource and stockholder (e.g. Wuswu incay hwakpolul uyhan nolyek 'Making every effort to secure excellent human resources'; Kwusengwentuluy changuysengi choytayhan palhwuytol swu issnun chocik mwunhwa coseng 'Establishing an organizational culture to help employees reach their full potential'; Cwисwu kachilul choywusenulo hanun kyengyeng 'Management placing stockholders as highest priority'). In particular, customer focus is most intensified (e.g. Kokaykuy chapyelhwatoyn kachi ceykong 'Creating value for customer'; Kokaykuy swumun yokwulul chacanayko 'Finding customer's hidden needs'; Kokayk mancokul silkyen 'Realizing customer satisfaction'; Kokaykkachi cwungsimulo iluy wusenswunuylul caypeyn 'Reforming business system according to customer value') This finding goes side by side with LG's humanoriented management principle, "Creating value for customers" and "Respecting human dignity." However an ethical code, integrity described by Jeong-Do management, is not articulated. Besides the value of people orienation, LG's management strategy in their CEO's greeting calls for steady growth as shown in Milay yeklyangey tayhan thwuca hwaktay 'Increasing investment on future capability', Saylowun sengcangtonglyekul palkwulhako wukseng 'Finding and developing new growth drivers', and Cisokcekin sengkwa 'sustainable achievement'. 


\subsection{Samsung Electronics}

Among five Samsung Electronics' Values (People, Excellence, Change, Integrity, Coprosperity), excellence seems the most highly valued by Samsung Electronics' CEO as follows: Choykouy cheyphwumkwa sepisulul thonghan sahoykonghen 'Contributing to society by creating superior products and service'; Pulayntu sangsunglyul seykyey 1uy kiepi toyesssupnita 'Our steady ascent in brand value has placed us shoulder to shoulder with global no. 1 company'; Choillyu kiepulo toyak 'taking the leap to becoming a (super) no. 1 corporation'; Choillyu cocikmwunhwalul changco 'Establishing a (super) no. 1 corporate culture'. This highlighted value of excellence seems irrelevant to what Samsung Electronics intensify as official corporate values, integrity and co-prosperity, as shown in section 3.3 (i.e. "We comply with laws and ethical standards" and "We maintain a clean organizational culture"; "We care for the environment, health and safety" and "We are a socially responsible corporate citizen").

As in the case of Hyundai Motors, furthermore, Cisokseng 'sustainability', Sangsayng 'coprosperity', and Kokayk 'customer' are also mentioned in the CEO's greeting in Samsung Electronics (e.g. Sinsengcang momeynthemul hwakpo 'Creating momentum for new growth'; Cisokcek sengcang 'sustainable growth'; Sangsaynguy kyengyengul silchen 'Fulfilling coprosperity management'; Kiepuy sahoycek chaykimul taham 'Making every effort to take corporate social responsibility'; Kokaykkwa cwucwulul choywusenulo hanun kyengyeng 'Management placing customers and stockholders as our highest priority').

Codes of conduct in Korean CEO's on-line greetings are summarized in table 3. Table 3 clarifies that Hyundai Motors put stress on globalization (e.g. kullopel kyengyeng cheyceykwuchwuk 'establishment of a global management system'), LG customer values (e.g. 
kokaykmancokul silhyen 'realization of customer satisfaction'), and Samsung Electronics excellence (e.g. choillyu kiepulo toyak 'take the leap to becoming a (super) no. 1 corporation').

This study supports the claim that each company's CEO pays particular attention to different values. CEO's particular language choices might be in an "attempt to purposefully communicate the values of the organization and the preferences of leaders" (Hartelius \& Browning 2008: 18)". 


\begin{tabular}{|c|c|c|c|}
\hline & Language components & & \\
\hline $\begin{array}{l}\text { Global } \\
\text { orientation }\end{array}$ & $\begin{array}{l}\text { Establishing a global } \\
\text { management system } \\
\text { - } \text { Global car maker } \\
\text { - } \text { Taking the leap to becoming a } \\
\text { global leader } \\
\text { - Management stabilization of } \\
\text { global manufacturing } \\
\text { footprints } \\
\text { - } \\
\text { eveloping into a global no. } 1 \\
\text { corporation } \\
\text { Taking global corporate social } \\
\text { responsibility }\end{array}$ & & \\
\hline $\begin{array}{l}\text { People } \\
\text { (customer, in } \\
\text { particular) }\end{array}$ & $\begin{array}{l}\text { - Innovation for customers as } \\
\text { our mid-to long-term vision } \\
\text { usiness philosophy placing } \\
\text { customers as our highest } \\
\text { priority }\end{array}$ & $\begin{array}{l}\text { - Creating value for customer } \\
\text { - Finding customer's hidden needs } \\
\text { - Realizing customer satisfaction } \\
\text { - Reforming business system } \\
\text { according to customer value' } \\
\text { 'Making every effort to secure } \\
\text { excellent human resources }\end{array}$ & $\begin{array}{l}\text { anagement placing customers and } \\
\text { stockholders as our highest priority }\end{array}$ \\
\hline
\end{tabular}




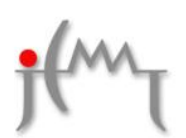

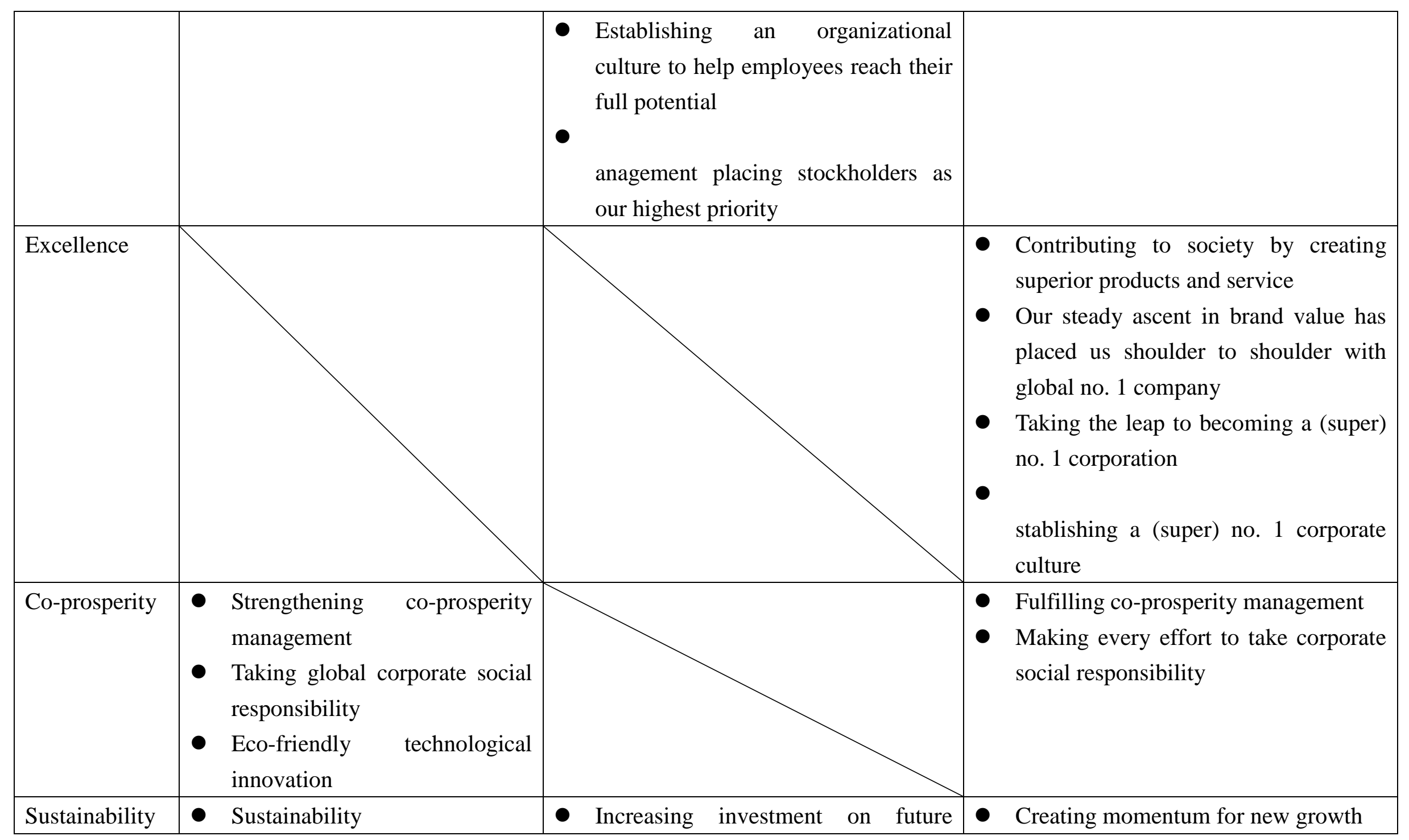




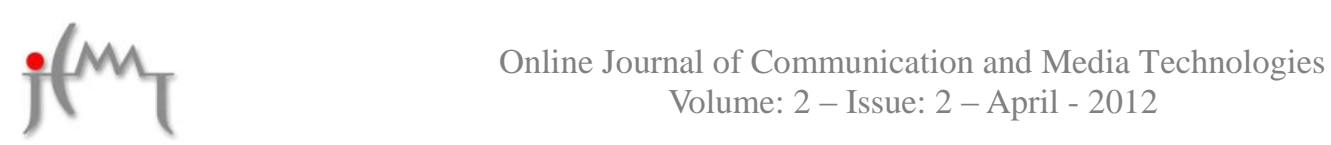

\begin{tabular}{|l|l|l|l|}
\hline & & capability & Sustainable growth \\
& & $\begin{array}{l}\text { Finding and developing new growth } \\
\text { drivers }\end{array}$ & \\
\hline
\end{tabular}

Table 3. Codes of conduct in Korean CEO's on-line greetings 
This study identifies language components CEOs have used to articulate their business strategy. It suggests language options that CEOs should consider when formulating messages about the business strategies they envision. Preliminary data analysis shows that communication orientation to stakeholders in CEO's on-line greetings is different across companies. In other words, "the degree of intensity" is differentiated by CEOs in the choice of management's language (Ran and Duimering 2007). This finding shows that actual code of conduct emphasized by each CEO is not necessarily going along well with corporation's key values, as clarified in the following figure. Figure 4 shows that a highlighted value matches with a key value only in LG.

Highlighted value

- Global

Hyundai orientation

- Customer value

LG

Samsung

Key value

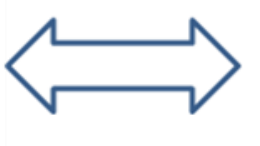

- Innovation for customers

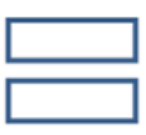

- Jeong-Do management

- Integrity

Figure 4. Each company's key and highlighted values

The highlighted values in on-line public relations communication meet different perspective 
of communication orientations (i.e. self-orientation vs. other-orientation). LG orients to customers (not themselves or their product in corporate value (other-orientation)), as their management principles, "Creating value for customers" and "Respecting human dignity" show. In contrast, Hyundai and Samsung's values in their on-line public relations communications are self-oriented (i.e. Hyundai product's globalization; Samsung product's excellence). Although their original key values are pertaining to other-orientation (i.e. customer-focus innovation in Hyundai; integrity (clean image to publics) in Samsung), their highlighted values are such self-oriented as global orientation and excellence.

\section{Discussion}

This study exemplifies prior orientation to work and priorities in what Korean companies want from their work. Unlike each corporation's official key values, highlighted values in CEO's greeting genres show their actual 'orientation to work' (Watson 2008). The concept of work orientation explains the factors, which influence people's attitudes and behavior with regard to their work. According to Watson (2008: 56-57, emphasis is mine), the concept of 'orientations to work' is "links between actions in the workplace and the external community and cultural life of employees". The orientations perspective takes the employee's own definition of the situations as an 'initial basis for the explanation of their social behavior and relationships' (Goldthorpe et al. 1968). This definition tends to focus on the 'needs' of workers. According to Watson's definition, the notion of work orientation is limited to the employee's 'needs'. He has a tendency to pay attention to needs of employees in defining the concept of the work orientation. His definition is originated from 'human identity', who or what a particular person is, in relation to others. He defines human identity as in what ways any given individual is like other people and in which ways they differ from others. There are two broad aspects of 'human identity': the internal self-identity and the external social- 
identity - the former being personal and the latter cultural or discursive (Watson 2008). According to Watson's definition of work orientation, employees might opt for work that allowed them more scope to express their own identities, actually self-identity (internal aspect of human identity; the individual's own notion of who and what they are).

Employees may also display varying priorities, attitudes and interests, depending on the context. Namely, every employee may have different priorities at different times and in different contexts. The growing recognition that people bring their own meanings to their work and that these meanings or work orientations may change over time. A person's orientation to work is the meaning attached by people to their work which predisposes them to think and act in particular ways with regard to that work (Watson 2008: 239). People may strive to shape a relatively cohesive notion of self-identity and struggle to negotiate with the various social-identities pertaining to them in the various contexts. Employees' work orientation is substantially affected by needs of companies. Company may require employees to "surrender a degree of personal autonomy" (Watson 2008: 300). Work-orientation in company (Hyundai's globalization; LG's customer value; Samsung's excellence) is likely to fail to meet worker's needs-oriented identity work. In this occasion, employees may need to adjust to this requirement and accommodate it. This is the case that self-identity is superseded by social-identity, external aspect of human identity: cultural, discursive or institutional notions of who or what any individual might be. This claim may raise us questions about identity work: how much scope do companies allow employees to express their own identities?; which identity goes first between self-identity and social-identity? 


\section{Concluding remarks}

This study exemplifies that the complexity of management's strategic concerns and its language choices to articulate major concerns of the study suggest a useful story about the language of management (Rogers et al. 2011).

Since rhetoric, action, and identity are interdependent in management strategy, as Eccles \& Nohria (1992) argue, it seems of interest to investigate rhetoric as identity for future analyses. Also work orientations are dynamic and work priorities are changing, so that historical case study to identify language components CEOs use to articulate shifts in their code of conduct should be meaningful.

This study can also be applicable for teaching business, in that it shows the management's language use in contemporary business world. Given this study, students can be benefited to learn rhetorical devices and linguistic choices relevant to company background information. 


\section{References}

Bird, S. (2007). Sensemaking and identity: The interconnection of storytelling and networking in a woman's group of a large corporation, in Journal of Business Communication, 44, 311-339.

David, C., \& Graham, M. B. (1997). Conflicting values: Team management portrayed in epic metaphors, in Journal of Business and Technology Communication, 11, 24-48.

Eccles, R. G., \& Nohria, N. (1992). Beyond the hype: Rediscovering the essence of management, Cambridge, MA, Harvard Business School Press.

Fairhurst, G.T. (2005). Reframing the art of framing: Problems and prospects for leadership in Leadership, 1, 165-185.

Fairhurst, G.T. Jordan, J.M., \& Newwirth, K. (1997). Why are we here? Managing the meaning of an organization mission statement, in Journal of Applied Communication Research, 25, 243-263.

Goffman, E. (1974). Frame analyses, New York, NY, Harper \& Row.

Goldthorpe, J.H, Lockwood, D., Beckhofer, F., \& Platt, J. (1968). The Affluent Worker: Industrial Attitudes and Behaviour, Cambridge, Cambridge University Press.

Hartelius, E.J., \& Browning, L.D. (2008). The application of rhetorical theory in managerial research: A literature review, in Management Communication Quarterly, 22, 13-39.

Jung, Y. (2007). Special lecture on public relations communication. Invited talk at Corporate Communication seminar at Department of Languages and Communication, Aalto University School of Economics.

Kirby, E.L, \& Harter, L.M. (2003). Speaking the language of the bottom-line: The metaphor of "managing diversity", in Journal of Business Communication, 40, 28-49.

Lakoff, G. (2004). Don't think of an elephant, White River Junction, VT, Chelsea Green.

Ran, B., \& Duimering, P.R. (2007). Imaging the organization: Language use in organizational 
identity claims, in Journal of Business and Technology Communication, 21, 155-187.

Rogers, P., \& Swales, J.M. (1990). We the people? An analysis of the Dana Corporation policies document, in Journal of Business Communication, 27, 293-313.

Rogers, P., Gunesekera, M., \& Yang, M. L. (2011). Language Options for Managing Dana Corporation's Philosophy and Policy Document. Journal of Business Communication. 48(3). 256-299.

Suchan, J. (1992). The effect of organizational metaphors on writers' stylistic choices, in Technical Communication, 39(1), 139-141.

Watson, T.J. (2008). Managing identity: identity work, personal predicaments and structural circumstances, in Organization, 15(1), 121-143.

Hyundai Motors website (http://www.hyundai.com/kr/)

LG Corp. website (http://www.lg.co.kr)

Samsung Electronics' website (http://www.samsung.com/sec)

Wikipedia (http://en.wikipedia.org/wiki/Hyundai_Motor_Company)

Wikipedia (http://en.wikipedia.org/wiki/Lg_group)

Wikipedia (http://en.wikipedia.org/wiki/Samsung_Electronics) 

Volume: 2 - Issue: 2 - April - 2012

\section{APPENDIX}




\section{Appendix A}

CEO's on-line greeting in Hyundai Motors

현대자동차는 중장기 비전인 '고객을 위한 혁신 (Innovation for Humanity)'을 목표로 지속적인 글로벌 경영체제 구축과 품질향상을 통해 브랜드 가치가 상승하고 있습니다. 현대자동차는 글로벌 자동차 메이커로 자리매김하고 있습니다.

현대자동차는 글로벌 리더로 도약해 나갈 것입니다.

미국, 중국, 인도, 유럽 등 글로벌 생산거점의 경영 안정화를 통해 글로벌 초일류 기업으로 성장할 수 있는 기반을 갖추었습니다.

고객을 최우선으로 하는 경영철학을 반영하여 브랜드와 감성품질 수준을 향상시켜 현대자동차의 가치를 더욱 높이겠습니다.

동반 성장을 위한 상생경영을 강화하고 글로벌 사회공헌 활동을 확대하여 성숙한 기업시민으로서의 책임을 다하겠습니다.

지구촌 인류행복의 근원인 환경을 위한 기술을 개발 보급하여 지속가능한 풍요로운 미래를 열어가는 기업이 되겠습니다. 


\section{Appendix B}

CEO's on-line greeting in LG

$\mathrm{LG}$ 는 고객의 차별화된 가치를 제공하는 것이 사업의 목적입니다.

고객의 숨은 요구를 찾아내고 고객 만족을 실현할 수 있는 제품과 서비스를 출시함으로써 시장 트랜드에 대응할 수 있는 체제를 갖추어 시장을 선도해 나가겠습니다.

미래의 변화를 주도하기 위해 미래 역량에 대한 투자를 확대해 나감으로써 필요한 역량확보에 만전을 기하겠습니다.

$\mathrm{LG}$ 의 미래를 담보할 새로운 성장동력을 발굴하고 육성해 나갈 것입니다.

가치 창출의 원천인 우수 인재 확보를 위한 노력을 강화하겠습니다.

시장과 고객가치 중심으로 일의 우선순위를 재편하여 지속적인 성과를 창출할 수 있는 강한 조직을 만들어 나가겠습니다.

구성원들의 창의성이 최대한 발휘될 수 있는 조직 문화 조성에 만전을 기하겠습니다. 주주 가치를 최우선으로 하는 경영을 통해 $\mathrm{LG}$ 를 일등 기업으로 발전시켜 나갈 것을 약속하겠습니다. 


\section{Appendix C}

CEO's on-line greeting in Samsung Electronics

삼성전자는 ‘최고의 제품과 서비스를 통한 사회공헌’이라는 경영이념을 실현하고자 노력을 기울여 왔습니다.

삼성전자는 최근 6 년간 브랜드 상승률 세계 1 위 기업이 되었습니다.

종합 전자업체로서의 글로벌 브랜드 구축이 고객 및 주주 여러분의 지속적인 관심과 애정이 바탕이 된 만큼, 삼성전자는 ‘고객과 주주를 최우선으로 하는 경영’을 펼쳐 나가기 위해 최선을 다할 것을 약속드립니다.

초일류 기업으로 도약하기 위한 신성장 모멘텀을 확보하는데 주력하고, 디지털 시대에 맞는 초일류 조직문화를 창조해 나가겠습니다.

나눔과 상생의 경영을 실천하고, 보다 풍요로운 사회를 위해 기업의 사회적 책임을 다함으로써 지속적으로 성장해 나가기 위해 노력하겠습니다. 